\title{
Distribution of IL-1 $\beta$ immunoreactive cells in pancreatic biopsies from living volunteers with new-onset type 1 diabetes: comparison with donors without diabetes and with longer duration of disease
}

\author{
Shiva Reddy ${ }^{1} \cdot$ Lars Krogvold $^{2,3} \cdot$ Charlton Martin $^{1} \cdot$ Rebecca Holland $^{1} \cdot$ Jaimin Choi $^{1} \cdot$ Hannah Woo $^{1} \cdot$ Fiona Wu $^{4}$. \\ Knut Dahl-Jørgensen ${ }^{2,5}$
}

Received: 13 December 2017 / Accepted: 14 February 2018 /Published online: 27 March 2018

(C) Springer-Verlag GmbH Germany, part of Springer Nature 2018

\begin{abstract}
Aims/hypothesis Although IL-1 $\beta$ is considered a key mediator of beta cell destruction, its cellular expression in islets during early type 1 diabetes remains unclear. We compared its expression in rare pancreatic biopsies from new-onset living volunteers with its expression in cadaveric pancreas sections from non-diabetic autoantibody-positive and -negative individuals and those with long-standing disease.

Methods Pancreatic biopsy sections from six new-onset living volunteers (group 1) and cadaveric sections from 13 non-diabetic autoantibody-negative donors (group 2), four non-diabetic autoantibody-positive donors (group 3) and nine donors with diabetes of longer duration (0.25-12 years of disease; group 4) were triple-immunostained for IL- $1 \beta$, insulin and glucagon. Intra- and peri-islet IL-1 $\beta$-positive cells in insulin-positive and -negative islets and in random exocrine fields were enumerated.

Results The mean number of IL- $1 \beta$-positive cells per islet from each donor in peri- and intra-islet regions was $<1.25$ and $<0.5$, respectively. In all study groups, the percentage of islets with IL-1 $\beta$ cells in peri- and/or intra-islet regions was highly variable and ranged from $4.48 \%$ to $17.59 \%$ in group $1,1.42 \%$ to $44.26 \%$ in group $2,7.93 \%$ to $17.53 \%$ in group 3 and $3.85 \%$ to $42.86 \%$ in group 4 , except in a single case where the value was $75 \%$. In $25 / 32$ donors, a higher percentage of islets showed IL-1 $\beta$-positive cells in peri-islet than in intra-islet regions. In sections from diabetic donors (groups 1 and 4 ), a higher mean number of IL-1 $\beta$ positive cells occurred in insulin-positive islets than in insulin-negative islets. In group 2, 70-90\% of islets in 3/13 sections had weak-to-moderate IL-1 $\beta$ staining in alpha cells but staining was virtually absent or substantially reduced in the remaining groups. The mean number of exocrine IL-1 $\beta$-positive cells in group 1 was lower than in the other groups.

Conclusions/interpretation At onset of type 1 diabetes, the low number of islet-associated IL- $1 \beta$-positive cells may be insufficient to elicit beta cell destruction. The variable expression in alpha cells in groups $2-4$ suggests their cellular heterogeneity and probable physiological role. The significance of a higher but variable number of exocrine IL- $1 \beta$-positive cells seen in nondiabetic individuals and those with long-term type 1 diabetes remains unclear.
\end{abstract}

Keywords Cytokines $\cdot$ Immunohistochemistry $\cdot$ Interleukin- $1 \beta \cdot$ Islet cells $\cdot$ New-onset type 1 diabetes

Electronic supplementary material The online version of this article (https://doi.org/10.1007/s00125-018-4600-8) contains peer-reviewed but unedited supplementary material, which is available to authorised users.

Shiva Reddy

s.reddy@auckland.ac.nz

1 Department of Molecular Medicine and Pathology, Faculty of Medical and Health Sciences, University of Auckland, Private Bag 92019, Auckland, New Zealand
2 Division of Paediatric and Adolescent Medicine, Oslo University Hospital, Oslo, Norway

3 Faculty of Dentistry, University of Oslo, Oslo, Norway

4 Diabetes Unit, Auckland District Health Board, Auckland, New Zealand

5 Faculty of Medicine, University of Oslo, Oslo, Norway 


\section{Research in context}

\section{What is already known about this subject?}

- Long-term exposure of human islets in culture to IL-1 $\beta$ with IFN- $\gamma$ and/or TNF- $\alpha$ leads to beta cell toxicity

- Exposure to lower concentrations of IL-1 $\beta$ and shorter incubation period result in glucose-stimulated insulin release

\section{What is the key question?}

- Is IL-1 $\beta$ expressed within and around the islets during early type 1 diabetes?

\section{What are the new findings?}

- Low numbers of IL-1 $1 \beta$-positive cells are present in and around islets from individuals with new-onset diabetes

- There is an increase in IL-1 $\beta$-positive cells in exocrine regions of some non-diabetic individuals and those with longerterm diabetes, probably as a result of pre-existing complications and hospitalisation

- Selective macrophages, T cells and alpha cells express IL-1 $\beta$

\section{How might this impact on clinical practice in the foreseeable future?}

- Successful clinical prevention of type 1 diabetes may require blockade of as-yet unidentified multiple beta cell destructive pathways

\begin{abstract}
Abbreviations
DiViD Diabetes Virus Detection study

LPS Lipopolysaccharide

MAPK Mitogen-activated protein kinase

nPOD Network for Pancreatic Organ Donors with Diabetes
\end{abstract}

\section{Introduction}

IL-1 $\beta$, an important proinflammatory cytokine, is expressed by a variety of cell types and displays pleiotropic actions, playing a key role in innate and adaptive immunity, immune cell communication, inflammation and neuronal, metabolic and endocrine processes [1]. Several earlier studies employing cultured islets demonstrated its toxicity towards beta cells and led to the premise that it is of vital importance in the pathogenesis of type 1 diabetes in humans [2-7]. Prolonged exposure of human islets to IL- $1 \beta$, in the presence of either IFN- $\gamma$ or TNF- $\alpha$, impairs glucose-stimulated insulin secretion and promotes beta cell death [5-7]. Binding of IL-1 $\beta$ to its cognate receptor on beta cells in vitro results in activation of prominent downstream intracellular gene networks and signalling events [8]. These include activation of mitogenactivated protein kinase (MAPK), signal transducer and activator of transcription 1 (STAT1) and NFKB, resulting in endoplasmic reticulum and mitochondrial stress and local production of various oxidant species, such as nitric oxide and superoxide anions $[4,7,9,10]$.
Is IL-1 $\beta$ toxic to the beta cell during early type 1 diabetes? If so, are the deleterious processes mediated, in part, by IL- $1 \beta$ within or close to the islet? In vivo effects of IL- $1 \beta$ on beta cell destruction are complicated by studies that point to bimodal opposing effects of the cytokine on beta cells; at lower concentrations and shorter exposure period it promotes insulin release, anti-apoptotic effects and beta cell proliferation while at higher concentrations and longer exposure period it inhibits glucose-stimulated insulin release and promotes beta cell death $[7,10-13]$.

Crucial evidence indicating a direct pathogenic effect of IL$1 \beta$ originating within the islet during development of type 1 diabetes has been lacking due to the scarcity of studies clarifying the level of cytokine expression in pancreases of humans with early disease. Most studies have analysed isolated islets from normal and type 2 diabetic pancreas from deceased individuals at the mRNA level, which may not correlate with the translated protein $[9,14]$. Since mRNA and western blotting analyses involve initial disruption of islet integrity, vital information regarding the spatial juxtaposition of cytokineexpressing cells in relation to the islets and islet cells is unavailable. Based on findings from pancreatic sections from individuals with type 1 diabetes, we speculated that isletinfiltrating leucocyte subsets in the peri- and intra-islet regions may release a variety of beta cell toxic factors, including IL$1 \beta$ and various oxidants involved in nitrosative stress $[15,16]$.

The deleterious effects of IL-1 $\beta$ on human beta cells in vitro and in animal studies have prompted recent multicentre clinical trials in volunteers with recent-onset type 1 diabetes, using strategies involving systemic blockade of IL$1 \beta$ or its receptor $[10,17]$. The inefficacy of such interventions 
calls for a re-examination of the pathogenic role of IL-1 $\beta$ in type 1 diabetes and we ask whether the cytokine is indeed expressed locally at a level toxic to beta cells [17]. Studies on its cellular expression within the islets during the early stages of disease have been severely limited by the scarcity of suitable pancreatic samples. In a previous report from Japan, six pancreatic biopsy samples from adult living donors showed the presence of IL- $\beta$ and TNF- $\alpha$ predominantly in selective macrophages and dendritic cells, although a clear cellular enumeration was not fully established [18]. The expression patterns reported in this previous study may not be generalisable to all individuals with new-onset diabetes in view of the known heterogeneous immunopathogenesis of type 1 diabetes, disparate rates of beta cell destruction and differing ethnic and environmental determinants. Thus, there is an urgent need to examine additional high-stringency pancreatic samples from individuals with new-onset diabetes, who have different demographics and are from dissimilar geographic locations.

Here, we applied combined immunohistochemical techniques to investigate the expression of IL- $1 \beta$ in sections of surgically retrieved pancreatic biopsies from six living volunteers with recent-onset type 1 diabetes who were of Norwegian descent and were from the Diabetes Virus Detection study (DiViD) [19]. We also quantified and determined the spatial distribution of IL-1 $\beta$-positive cells within and close to beta cell-positive and -negative islets and exocrine areas, and compared our findings with those from cadaveric pancreatic samples taken from individuals with longer duration of disease and from non-diabetic autoantibody-negative and -positive individuals, supplied by the Network for Pancreatic Organ Donors with Diabetes (nPOD) [20].

\section{Methods}

Experimental protocol and microscopy We immunostained and analysed paraffin-embedded pancreatic sections (5 $\mu \mathrm{m})$ from formalin-fixed biopsy specimens retrieved laparoscopically from six individuals with newly diagnosed type 1 diabetes, from DiViD [19]. Sections from 26 formalinfixed cadaveric pancreases supplied by nPOD were also analysed [20]. Approval was granted by the Norwegian Government's Regional Ethics Committee and for the Auckland study by the New Zealand Ministry of Health and Disability Ethics Committee (approval number NTX/11/EXP/ 092/AMO2). The main study groups are summarised in Table 1 and donor demographics are shown in electronic supplementary material (ESM) Table 1.

Relevant immunohistochemical steps, reagents and incubation times are summarised in ESM Table 2. Immediately prior to immunohistochemical analysis, sections were de-paraffinised, rehydrated and subjected to antigen retrieval with citrate buffer containing $0.05 \%$ (vol./vol.) Tween-20 (Sigma-Aldrich,
Darmstadt, Germany), washed twice with distilled water and exposed to $3 \%$ (vol./vol.) $\mathrm{H}_{2} \mathrm{O}_{2}$ for $15 \mathrm{~min}$. Following a further wash in distilled water, sections were equilibrated with immunohistochemical wash buffer $(0.1 \%$ vol./vol. Tween-20 in PBS, $\mathrm{pH} 7.4$ ) for $5 \mathrm{~min}$ and blocked with $5 \%$ vol./vol. normal goat serum (constituted in wash buffer) for $1 \mathrm{~h}$ at $37^{\circ} \mathrm{C}$. Sections were incubated with mouse anti-IL- $1 \beta$ (IgG concentration $1 \mu \mathrm{g} / \mathrm{ml}$ ) and then washed and incubated with anti-mouse IgG horseradish peroxidase polymer. After further washing, sections were exposed to SignalStain diaminobenzidine (DAB) substrate (catalogue no. 8059; Cell Signaling Technology, Danvers, MA, USA) for 4-5 min. A mixture of guinea pig anti-insulin serum and rabbit anti-glucagon serum in 5\% vol./vol. normal goat serum in PBS was then applied. Highly cross-adsorbed species-specific goat anti-guinea pig IgG-Alexa 568 plus goat anti-rabbit IgG-Alexa 488 in 5\% vol./vol. normal goat serum in PBS was applied and incubated as in the previous step and then sections were washed and prepared for microscopy.

The immunohistochemical specificity of anti-IL-1 $\beta$ (catalogue no. 12242; Cell Signaling Technology) has been validated by the manufacturer. Thus, by immunohistochemistry, it successfully detects IL- $1 \beta$ immunoreactive cells in human colonic sections from individuals with chronic colitis. Further, by western blotting, the same antibody detects mature recombinant human and mouse IL- $1 \beta$ and the human precursor (molecular mass of $34 \mathrm{kDa}$ ) in extracts of Raw 264.7 and human monocyte-derived THP-1 cells, following exposure to Brefeldin and lipopolysaccharide (LPS), respectively.

Anti-IL-1 $\beta$ was replaced with diluent to act as negative controls. As further controls, paraffin sections of THP-1 cells, harvested after incubation with LPS (100 ng/ml for $3 \mathrm{~h}$ ) and without (from Cell Signaling Technology), were evaluated in this laboratory for IL-1 $\beta$ immunohistochemical specificity. The immunostaining protocol for IL-1 $\beta$ was tested with formalin-fixed tonsil sections, supplied by Department of Surgery, University of Auckland.

Sections from selected pancreas and tonsil were immunostained for IL-1 $\beta$ in two separate sections. They were then exposed to rabbit anti-CD68 or rabbit anti-CD3, followed by donkey anti-rabbit IgG-biotin and then streptavidin-Alexa 568. Pancreatic sections were immunostained subsequently for insulin as above, followed by donkey anti-guinea pig IgG-Alexa 488.

Immunostained sections were examined with a Nikon Eclipse E600 epifluorescence-bright field microscope and digital images recorded. Group assignment was blinded to the investigator, except groups 1 and 4 where many islets were insulin-deficient. From each pancreatic section, islets with approximately $\geq 20$ endocrine cells were imaged for the presence of IL-1 $\beta$, insulin, glucagon, CD68 cells (macrophage marker) and CD3 cells ( $T$ cell marker). Each of the specific image sets from multiple acquisitions were merged with Adobe Photoshop CS6 (Adobe Systems, San Jose, CA, USA) 
Table 1 Summary of main study groups, including sex and age distribution

\begin{tabular}{lllll}
\hline Study group & $\begin{array}{l}\text { Sex } \\
\text { (no. female/no. male) }\end{array}$ & $\begin{array}{l}\text { Mean age } \\
\text { (years) }\end{array}$ & $\begin{array}{l}\text { Median age } \\
\text { (years) }\end{array}$ & $\begin{array}{l}\text { Age range } \\
\text { (years) }\end{array}$ \\
\hline Group 1, new-onset diabetes & $3 / 3$ & 28.83 & 28 & $24-35$ \\
Group 2, non-diabetic AAb-negative & $6 / 7$ & 24.74 & 24.5 & $5-44$ \\
Group 3, non-diabetic AAb-positive & $2 / 2$ & 26.41 & 25.5 & $17.65-37$ \\
Group 4, long-term diabetes & $5 / 4$ & 26.54 & 26.4 & $5-44$ \\
\hline
\end{tabular}

AAb, autoantibody following conversion of IL-1 $\beta$ immunostained cells to a greyscale fluorescence mode. Fifteen exocrine fields that were devoid of islet and ductal areas were selected randomly by microscopically traversing different regions of each pancreatic section and imaged at $\times 20$ objective. The number of IL- $1 \beta$ positive cells in each field was enumerated and the mean number per field per section determined. All data were included in the study.

For each section, the number of IL- $1 \beta$-positive cells in the peri- and intra-islet regions was enumerated and the mean number of cells per insulin-positive and -negative islet determined. Islets that showed immunostaining for IL-1 $\beta$ in alpha cells were scored microscopically as negative, weak or moderate intensity.

Data analysis The percentages of insulin-positive islets in pancreas sections from each donor were represented as bar graphs. The mean \pm SD number of IL-1 $\beta$-positive cells per islet, in peri- and intra-islet locations and in insulin-positive and -negative islets was determined, tabulated and represented as bar graphs. The percentage of islets containing IL-1 $\beta$ positive cells was determined for each section. The number of IL-1 $\beta$-positive cells in each exocrine field and the mean value per case were depicted graphically. Statistical analysis was performed using a generalised linear mixed model due to Poisson distribution of data to determine significance. Fixed effects were insulin positivity and negativity of the islet, location of IL-1 $\beta$ (peri-islet, intra-islet) and the type of group (four study groups) with case chosen as a random effect. Pairwise comparisons were also performed between fixed effects. The same statistical techniques were applied to exocrine IL-1 $\beta$ positive cell counts.

\section{Results}

Immunohistochemical staining pattern for IL-1 $\beta$ Application of the immunohistochemical procedure for IL- $1 \beta$ to THP-1 cells showed positive cytokine staining following prior exposure to LPS; no staining was seen without LPS (ESM Fig. 1a,b). In tonsil sections, weak-to-strong expression of the cytokine was observed in various regions, being co-localised in CD68 cells and absent in T cells (ESM Fig. 1c-f). Pancreatic sections from one nPOD donor (no. 6070) showed a few cells positive for IL$1 \beta$ in the peri-islet and exocrine regions but not after substitution of the primary antibody with diluent (ESM Fig. 1g-j).

The distribution of IL-1 $\beta$-positive cells within or close to islets and in the exocrine regions is shown in Fig. 1 for DiViD cases 1 and 2 and in ESM Figs 2 and 3 for cases 3-6. In case 1, almost all islets were devoid of beta cells, with a small minority of islets harbouring one or two IL-1 $\beta$-positive cells in either the peri-islet or intra-islet area (Fig. 1a,b,d,e). IL-1 $\beta$-positive cells were also rare in the exocrine region (Fig. 1c,f). This cellular distribution pattern was similar in DiViD donors 2-6, in whom a larger number of insulin-positive islets was observed. The distribution pattern was independent of the presence of remaining beta cells within islets and the presence of autoantibodies and their antigenic specificities (Fig. 1g-1, ESM Figs 2 and 3 and ESM Table 1).

The distribution of IL- $1 \beta$ immunoreactive cells in peri- and intra-islet regions and in exocrine areas in pancreases from three non-diabetic donors is illustrated in Fig. 2. In all three cases, IL-1 $\beta$-positive cells located in the peri- and intra-islet regions were present only rarely (Fig. 2a,b,d,e,g,h), with a few scattered cells in the exocrine region, usually in the pancreatic septa (Fig. 2c,f,i).

In nPOD diabetic cases 6209 and 6039, IL-1 $\beta$-positive cells were present only occasionally in the peri- and intraislet regions and exocrine areas (Fig. 3). However, the number of islet-associated IL- $1 \beta$-positive cells was slightly higher than in the non-diabetic donors (group 2) and DiViD donors with new-onset type 1 diabetes (Fig. 1, ESM Figs 2 and 3). In diabetic case 6070 (duration of type 1 diabetes 7 years), IL$1 \beta$-positive cells in the peri-islet and intra-islet areas were also rare, irrespective of the presence of residual insulin cells (ESM Fig. 4a,b,d,e,g,h). However, there was a marked increase in the number of IL-1 $\beta$-positive cells in the exocrine region, usually in the inter-acinar stroma and adjacent to pancreatic septa and pancreatic ducts. This increase may have been due to donor history of metabolic instability and diabetic ketoacidosis (ESM Fig. 4c,f,j,k and ESM Table 1).

In some nPOD donor pancreas sections, selective alpha cells showed IL-1 $\beta$ immunolabelling of variable intensity and examples are shown as paired images (Fig. 4). In the non-diabetic autoantibody-negative group, although moderate and weak immunolabelling in alpha cells were prominent in 
Fig. 1 Immunohistochemical analysis of pancreas sections from DiViD donors. IL-1 $\beta$-positive cells (brown or white) in pancreatic sections from DiViD cases $1(\mathbf{a}-\mathbf{f})$ and $2(\mathbf{g}-\mathbf{l})$, costained for insulin (red) and glucagon (green) are shown. Case numbers and duration of diabetes in weeks (w) are specified in (a, $\mathbf{g}) .(\mathbf{a}, \mathbf{d}, \mathbf{g}, \mathbf{j})$ Arrows indicate a few IL-1 $\beta$-positive cells in periand intra-islet regions; dotted line shows islet boundary. (b, e, h, k) Same field as $(\mathbf{a}, \mathbf{d}, \mathbf{g}, \mathbf{j})$ showing IL-1 $\beta$-positive cells (white arrows), merged with islet cells positive (h) and negative (b, e, k) for insulin. (c, f, i, l) Exocrine region where arrowheads indicate a few IL- $\beta$-positive cells. Scale bar, $50 \mu \mathrm{m}$ (applies to all micrographs). Glu, glucagon; Ins, insulin; T1D, type 1 diabetes

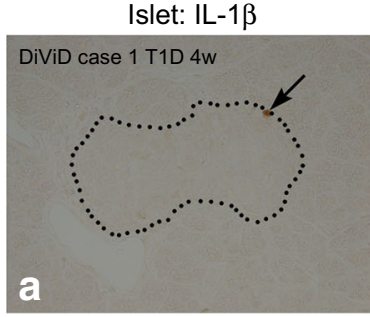

Islet: IL-1 \pm Ins + Glu

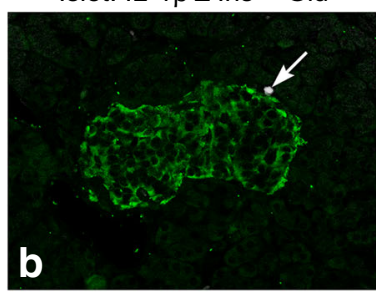

Exocrine: IL-1 $\beta$
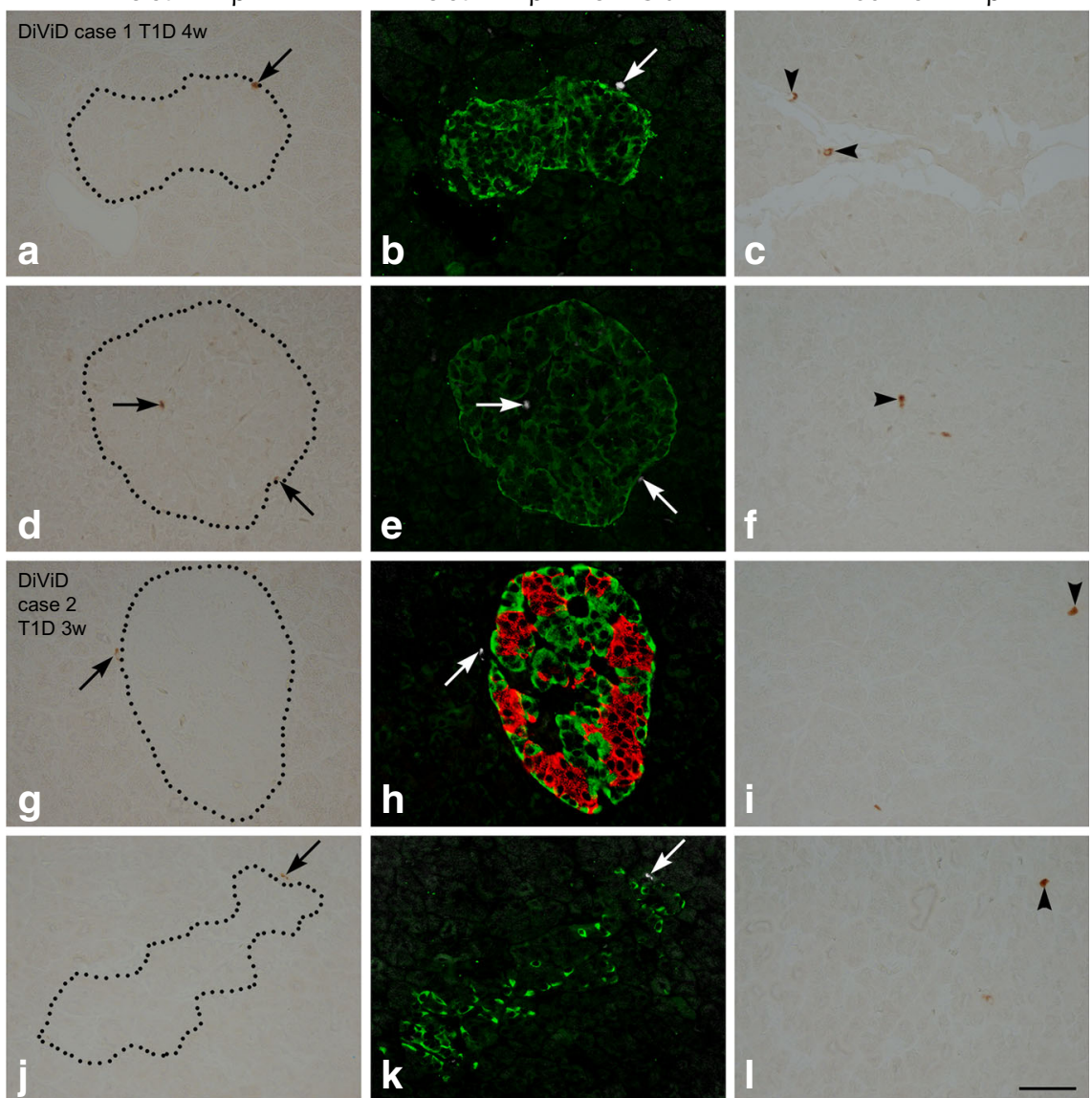

specific cases, islet to islet variability in the intensity of immunostaining within the same section was also observed (6160,
Fig. 4a-f; 6178, Fig. 4i,j) while it was absent or weak in other cases (6055, Fig. 4g,h). Expression was slightly more
Fig. 2 Immunohistochemical analysis of pancreas sections from non-diabetic autoantibodynegative nPOD cases $6179(\mathbf{a}-\mathbf{c})$, $6005(\mathbf{d}-\mathbf{f})$ and $6233(\mathbf{g}-\mathbf{i})$. IL-1 $\beta$ positive cells (brown or white) costained for insulin (red) and glucagon (green) are shown. (a, d, g) Arrows and arrowheads indicate a few IL- $1 \beta$-positive cells in peri-islet and exocrine cells, respectively; dotted line shows islet boundary. (b, e, h) Same field as (a, d, g) showing IL-1 $\beta$-positive cells (white arrows and arrowheads), merged with insulin- and glucagonpositive cells. (c, f, i) Exocrine region where arrowheads indicate a few IL- $\beta$-positive cells. Scale bar, $50 \mu \mathrm{m}$ (applies to all micrographs). Glu, glucagon; Ins, insulin; ND, non-diabetic

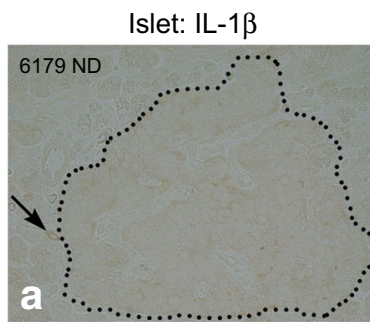

Islet: IL-1 $\beta+$ Ins + Glu
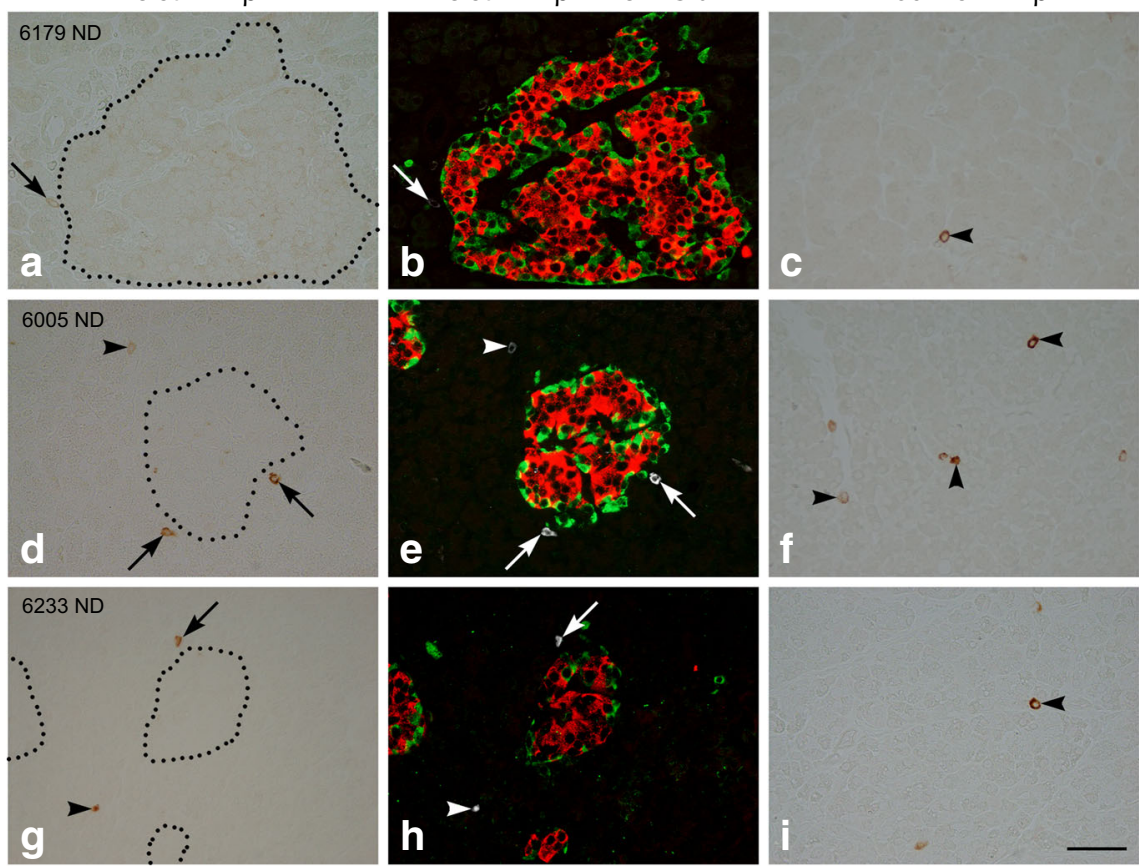
Fig. 3 Immunohistochemical analysis of pancreas sections from diabetic nPOD cases $6209(\mathbf{a}-\mathbf{f}$, diabetes duration 0.25 years) and $6039(\mathbf{g}-\mathbf{l}$, diabetes duration 12 years). IL-1 $\beta$-positive cells (brown or white) co-stained for insulin (red) and glucagon (green) are shown. $(\mathbf{a}, \mathbf{d}, \mathbf{g}, \mathbf{j})$ Arrows and arrowheads indicate a few IL- $1 \beta$ positive cells in peri- and intraislet and exocrine cells, respectively; dotted line shows islet boundary. (b, e, h, k) Same field as (a, d, $\mathbf{g}, \mathbf{j})$ showing IL- $1 \beta$ positive cells in white (arrows), merged with islets positive (b) and negative $(\mathbf{e}, \mathbf{h}, \mathbf{k})$ for insulin. $(\mathbf{c}, \mathbf{f}, \mathbf{i}, \mathbf{l})$ Arrowheads indicate a few IL- $1 \beta$-positive cells in exocrine region. Scale bar, $50 \mu \mathrm{m}$ (applies to all micrographs). Glu, glucagon; Ins, insulin; T1D, type 1 diabetes; $y$, years

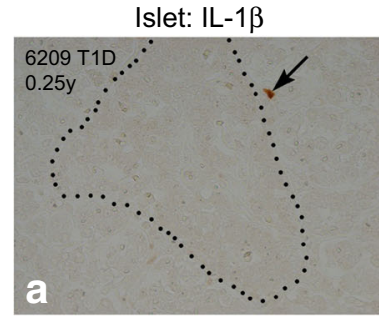

Islet: IL-1 \pm Ins + Glu
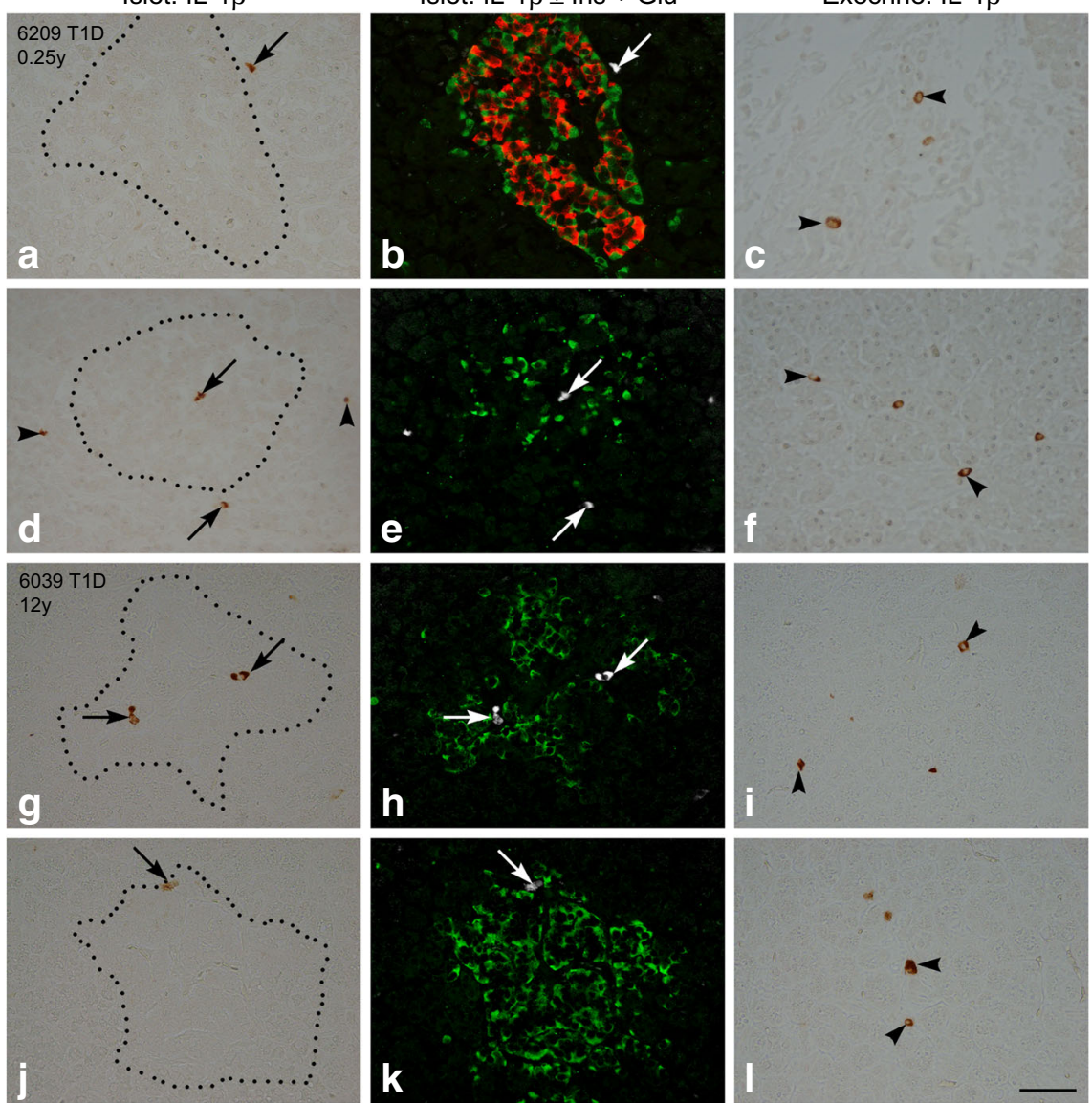

attenuated but variable in the non-diabetic autoantibody-positive group (6267, Fig. 4k-n) and most of the long-term diabetic group (6088 and 6211, Fig. 4o-t).

Dual staining of selected pancreas sections showed the expression of IL-1 $\beta$ in macrophages and occasionally $T$ cells (ESM Fig. 5a-1).

Cellular analysis Results of the morphometric analysis of islets, including the number of islets examined for each donor, are shown in ESM Tables 3-6. The percentage of insulin-positive islets found in each of the donors is shown in Fig. 5. In the nondiabetic groups, all islets had insulin-positive cells (Fig. 5b,c) but the percentage was highly variable in donors with newonset and long-standing diabetes (islets from DiViD case 1 and nPOD cases 6262, 6220 and 6039 from group 4 were insulin-negative; Fig. 5a,d). The percentage of islets with IL$1 \beta$ cells in peri- and/or intra-islet regions was highly variable amongst the 4 study groups $(4.48 \%$ to $17.59 \%$ in group 1 ; $1.42 \%$ to $44.26 \%$ in group $2 ; 7.93 \%$ to $17.53 \%$ in group 3 ; $3.85 \%$ to $42.86 \%$ in group 4 [excluding donor 6070: $75 \%$ ]; ESM Tables 3-6). The mean number of IL-1 $\beta$-positive cells per islet in peri- and intra-islet regions was $<1.25$ and $<0.5$, respectively (ESM Tables 3-6). The number of peri- and intraislet IL- $\beta$-positive cells was extremely low (usually fewer than two cells per islet region); the percentage of islets with IL-1 $\beta$ positive cells in peri- and intra-islet regions are shown in Fig. 5. In group 1 , four of the six donors showed a higher percentage of islets with IL-1 $\beta$-positive cells in the peri-islet region than in the intra-islet region (Fig. 5a) while in groups 2, 3 and 4, the percentages were higher in 10/13, 4/4 and 7/9 donors, respectively (Fig. 5b,c,d; ESM Tables 3-6). In group 1, the five donors with insulin-positive islets showed a higher mean number of IL-1 $\beta$-positive cells per islet in insulin-positive than in insulin-negative islets (Fig. 6a). This difference was also observed in the six donors from group 4 who had insulin-positive islets (Fig. 6d). Case 6070 (duration of type 1 diabetes 7 years) showed the highest number of IL-1 $\beta$-positive cells ( 2.27 cells per insulin-positive islet), probably attributable to the donor's clinical history of repeated hospitalisation, diabetic ketoacidosis, non-compliance with medications and metabolic de-compensation (Fig. 6d, ESM Table 6). In the same donor, the mean number of IL-1 $\beta$-positive cells was higher in the periislet region than in the intra-islet region (Fig. 6d, ESM Table 6).

For group 1, in the five donors who had insulin-positive islets, the overall mean number of IL- $1 \beta$-positive cells in the peri- and intra-islet region was higher in the insulin-positive islets $(0.205 \pm 0.449)$ than in insulin-negative islets $(0.09 \pm$ 0.364; ESM Table 3). The corresponding values in the $5 / 9$ 
Fig. 4 Immunohistochemical analysis of pancreas sections from non-diabetic autoantibodynegative nPOD cases $6160(\mathbf{a}-\mathbf{f})$, $6055(\mathbf{g}, \mathbf{h})$ and $6178(\mathbf{i}, \mathbf{j})$, nondiabetic autoantibody-positive nPOD case $6267(\mathbf{k}-\mathbf{n})$ and diabetic nPOD cases 6088 (o-r, type 1 diabetes duration 5 years) and 6211 (s, t, type 1 diabetes duration 4 years). Merged images of sections stained for insulin (red) and glucagon (green) are shown in the first and third column paired with corresponding sections triplestained for IL-1 $\beta$ (brown) in the second and fourth column. In (d, $\mathbf{h}, \mathbf{l}, \mathbf{n}, \mathbf{p}, \mathbf{r}, \mathbf{t})$ dotted line shows islet boundary. Black and white arrows point to weak and moderate staining for IL- $1 \beta$ in alpha cells; black and white arrowheads indicate negative staining in alpha cells. In $(\mathbf{r}, \mathbf{t})$, red arrows indicate IL- $1 \beta$-positive cells in non-alpha cells. In $(\mathbf{q}, \mathbf{r})$ alpha cells in an islet negative for IL-1 $\beta$ are shown. Three pairs of images for 6160 and two pairs for 6267 and 6088 are included to illustrate differences in intensity of IL- $1 \beta$ staining and its staining pattern within the same section. Scale bar, $50 \mu \mathrm{m}$ (applies to all micrographs). $\mathrm{AAb}^{+}$,

autoantibody-positive; $\mathrm{AAb}^{-}$, autoantibody-negative; ND, nondiabetic; T1D, type 1 diabetes; $\mathrm{y}$, years

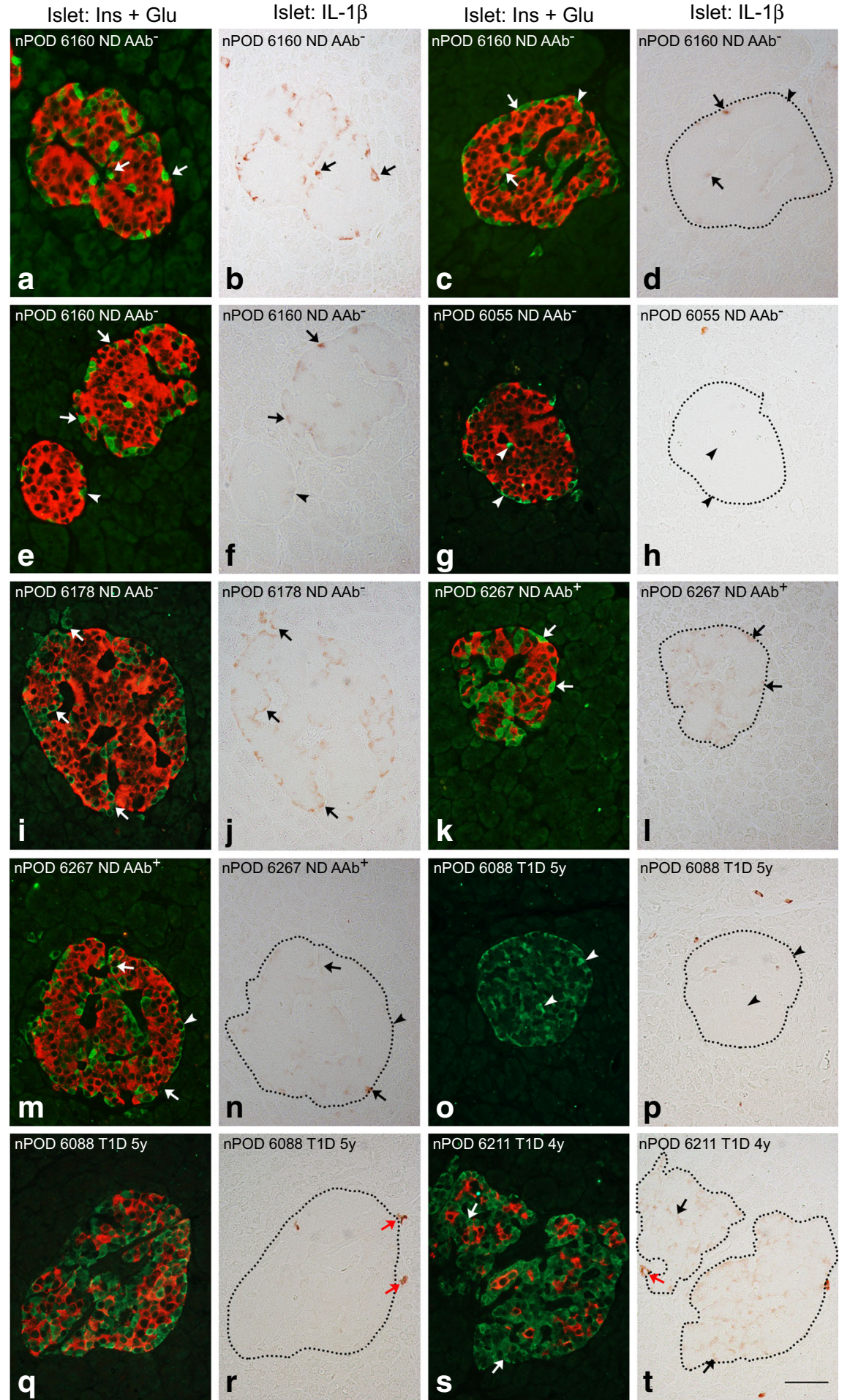

donors in the long-term diabetes group who had residual insulin positivity were $0.565 \pm 1.03$ and $0.257 \pm 0.581$, respectively (first five cases in ESM Table 6). These differences were not statistically significant.

The percentage of islets staining positive for IL- $1 \beta$ in alpha cells in donors from each group is shown in Fig. 7 and ESM Tables 3-6. In group 1, almost no staining was evident. In group
$2,3 / 13$ donors showed weak-to-moderate $\mathrm{IL}-1 \beta$ staining in alpha cells in $>70 \%$ of islets while in groups 3 and 4 , the percentages were markedly reduced $(4.8-31 \%$ and $0-52.4 \%$, respectively).

The number of IL-1 $\beta$-positive cells (peri- and intra-islet nonalpha cells) was significantly higher in group 4 than in group 3 $(p=0.01)$. In insulin-positive islets, the cell counts were significantly higher in group 3 than in groups $1(p=0.02)$ and $4(p=$ 
Fig. 5 Percentage of insulinpositive islets (black bars) in pancreatic sections from individuals belonging to groups 1 (a), 2 (b), 3 (c) and 4 (d). The total numbers of islets examined in each donor section are indicated in the second column of: (a) ESM Table 3; (b) ESM Table 4; (c) ESM Table 5 and (d) ESM

Table 6. White and dark grey bars show the percentage of islets with peri-islet and intra-islet (nonalpha cells) IL- $1 \beta$-positive cells, respectively. GADA, anti-GAD; IA-2A, anti-insulinoma associated antigen; IAA, insulin autoantibodies; ZnT8A, anti-zinc transporter 8 a

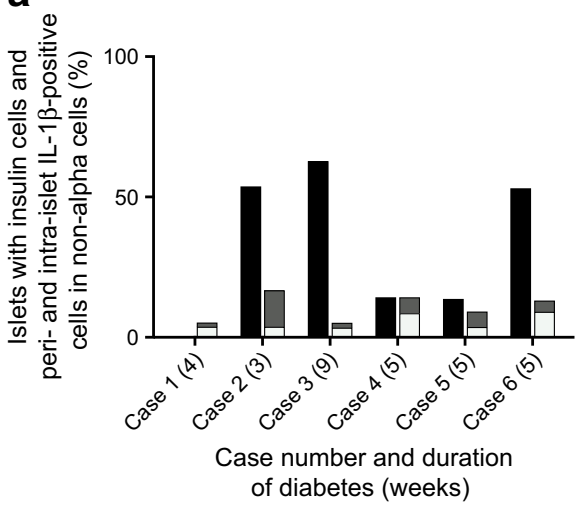

C

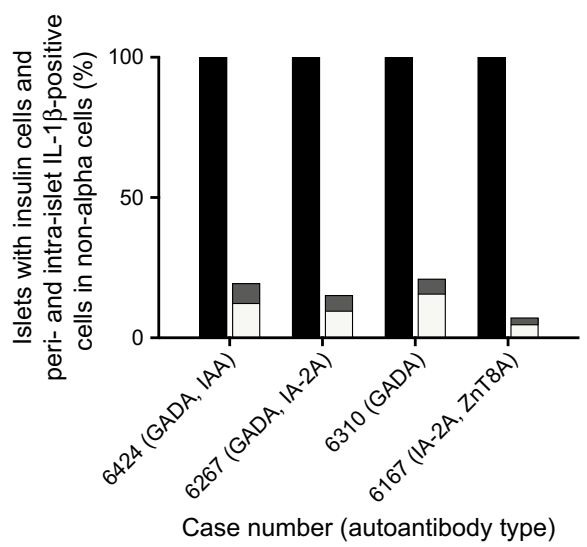

b

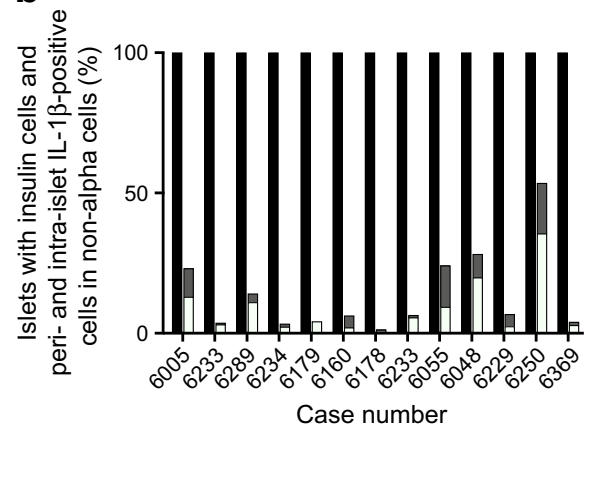

d

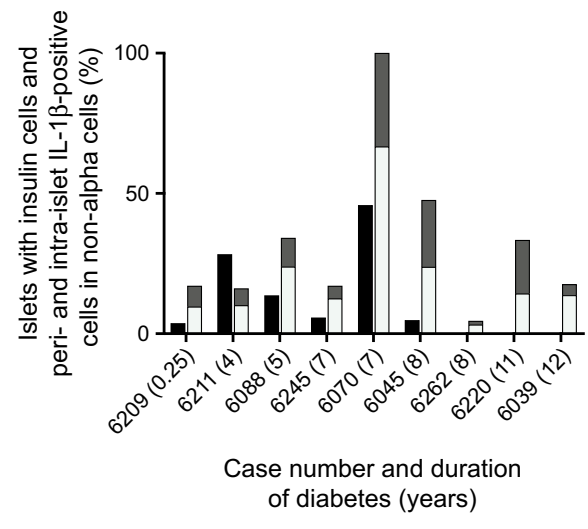

0.001). Insulin-negative islets from group 4 had a higher IL-1 $\beta$ positive cell count than group $1(p=0.041)$. However, the statistical difference may be due to the unusually higher cell counts in some donors with long-term diabetes (group 4).

The number of IL-1 $\beta$-positive cells in each of 15 random exocrine fields per individual donor is shown in Fig. 8. The mean values over the 15 exocrine fields were significantly lower in those with new-onset diabetes (group 1) than in the other three groups $(p=0.003)$. Although the overall exocrine cell counts in group 2 were lower than in group $4(p=0.031)$, inclusion of the unusually higher values for case 6070 (group 4) may have contributed to statistical significance.

\section{Discussion}

A role for IL- $1 \beta$ in beta cell integrity or demise is plausible due to the presence of its receptor at a high density on the beta cell surface [21]. Previous in vitro studies demonstrating deleterious effects on beta cells exposed to higher levels of IL-1 $\beta$, in combination with TNF- $\alpha$ and IFN- $\gamma$, led to the rationale that IL-1 $\beta$ blockade may arrest further destruction of beta cells in human type 1 diabetes $[6,10,12]$. However, IL-1 $\beta$ at lower levels may have a trophic effect on beta cells and thus enhance functional integrity and exert insulinotropic actions [13]. The true role of
IL- $1 \beta$ is further complicated by the presence of circulating soluble IL-1 $\beta$ receptors which may neutralise peripheral and tissue IL-1 $\beta$ bioactivity [7].

To clarify the proposed pathogenic role of IL-1 $\beta$ in early type 1 diabetes in vivo, we first determined whether the cytokine is expressed within or close to the islet in rare well-preserved pancreatic biopsies from six living volunteers with new-onset type 1 diabetes. Second, we determined whether this expression was dependent on the presence of residual beta cells within islets.

We demonstrate that, overall, the number of IL- $1 \beta$-positive cells is low within the peri- and intra-islet regions of individuals with new-onset diabetes. The few sparsely distributed IL-1 $\beta$ positive cells in the peri- and intra-islet non-alpha cells and in exocrine regions were independent of the presence of beta cells within the islets. In the islets of the donors with new-onset and long-term diabetes who had residual beta cells, a slightly higher overall mean number of IL- $1 \beta$-positive cells as noted in insulinpositive than in insulin-negative islets. Further analysis involving larger cohorts harbouring residual beta cells will be necessary to verify these differences. The markedly reduced number of IL$1 \beta$-positive cells in the islets of most donors from the four study groups suggests low but ongoing constitutive expression of the cytokine, independent of disease status. Thus, minimallyexpressed IL-1 $\beta$ within and around the islet may be trophic to beta and other islet cells. 
Fig. 6 Mean number of IL-1 $\beta$ positive cells in insulin-positive (black bars) and insulin-negative islets (light grey bars) in pancreatic sections from donors (c) and 4 (d). Also shown are mean number of IL-1 $\beta$-positive cells in peri-islet (white bars) and intra-islet non-alpha cells (dark grey bars). GADA, anti-GAD; IA-2A, anti-insulinoma associated antigen; IAA, insulin autoantibodies; ZnT8A, anti-zinc transporter 8 belonging to groups 1 (a), 2 (b), 3

a
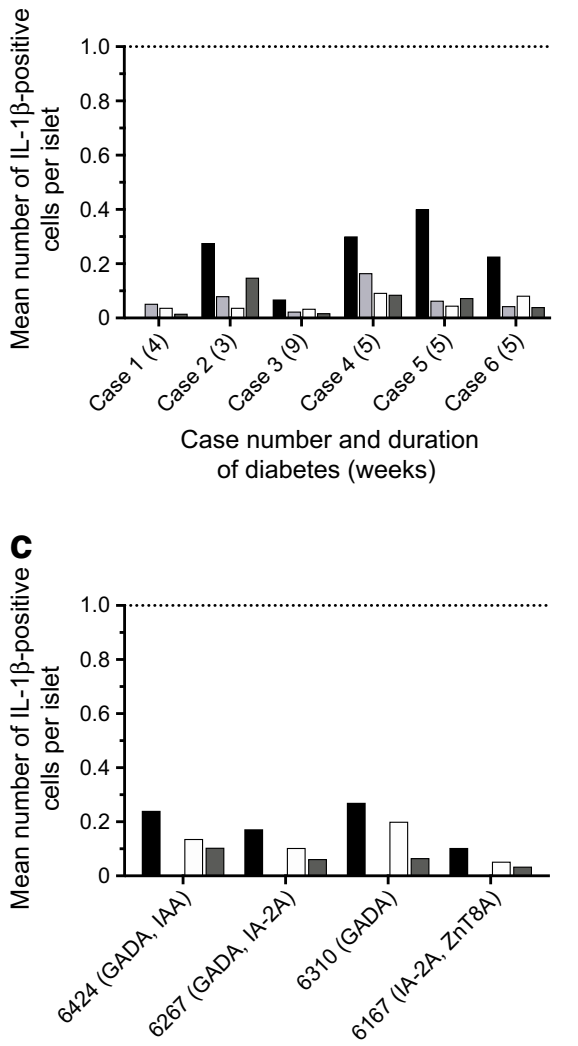

Case number (autoantibody type)

Fig. 7 Percentage of islets with weak (dark grey bars) and moderate (white bars) staining for IL-1 $\beta$ in alpha cells in pancreatic sections from donors belonging to groups 1 (a), 2 (b), 3 (c) and 4 (d). GADA, anti-GAD; IA-2A, antiinsulinoma associated antigen; IAA, insulin autoantibodies; ZnT8A, anti-zinc transporter 8 a

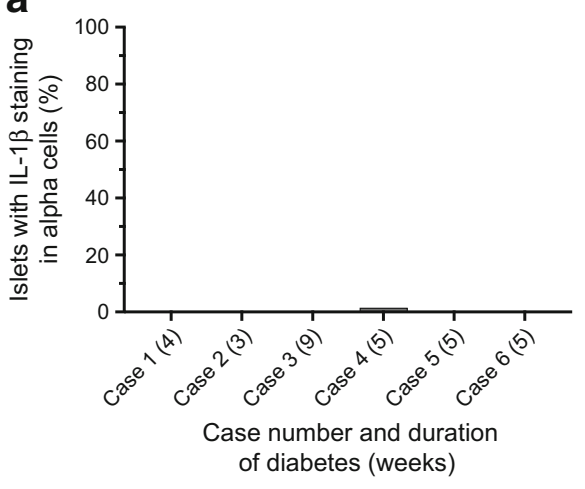

b
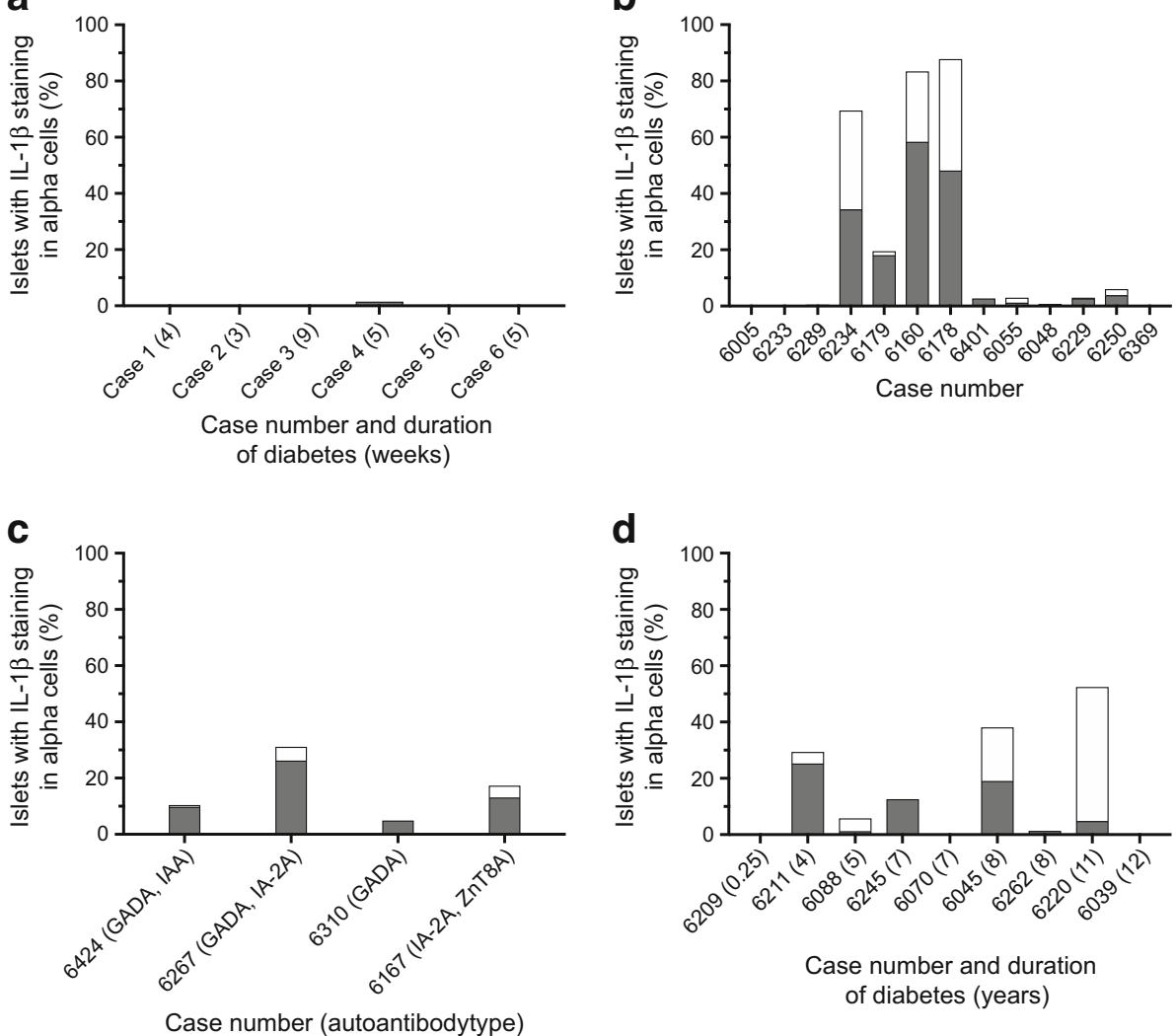
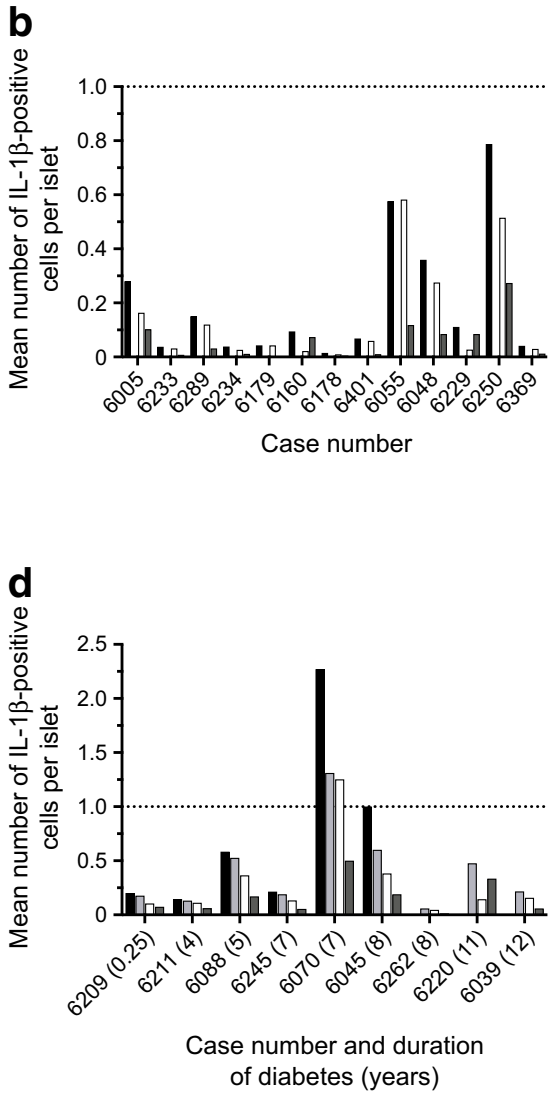
Fig. 8 Number of IL-1 $\beta$-positive cells in 15 random exocrine fields in each pancreatic section from donors belonging to groups 1 (a), 2 (b), 3 (c) and 4 (d). Horizontal bars indicate the mean values per donor. GADA, anti-GAD; IA-2A, anti-insulinoma associated antigen; IAA, insulin autoantibodies; ZnT8A, anti-zinc transporter 8
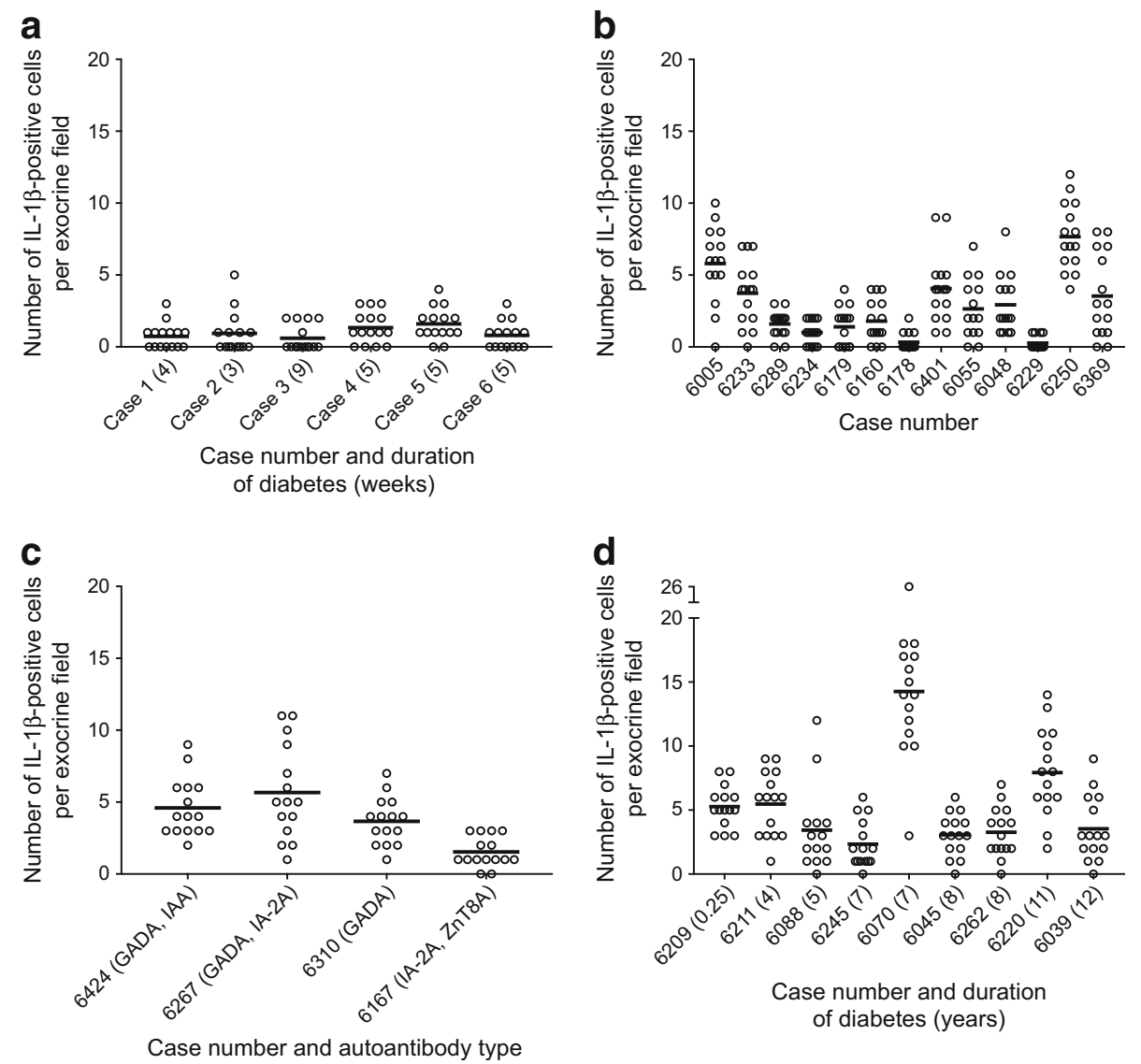

Our findings are in close agreement with those from a recent careful study, which quantified the level of various cytokine and chemokine genes, including IL-1 $\beta$, in laser-captured insulitic islets and in isolated islets from the same DiViD donors as employed here [22]. This previous study demonstrated extremely low levels of $I L 1 B$ mRNA in laser-captured islet sections as well as in isolated islets; IL-1 $\beta$ protein levels in isolated islets were also undetectable. $I L 1 B$ mRNA was also undetectable in laser-captured islet sections from deceased nPOD donors with type 1 diabetes (personal communication, I. Gerling, University of Tennessee Health Science Centre, Memphis, TN, USA). Previous studies showed only low basal levels of $I L 1 B$ mRNA in normal human islets cultured for $48 \mathrm{~h}$ to 7 days with increasing concentrations of glucose [9]. Interpretation of the latter data requires some caution, since mRNA and protein levels may change during islet isolation and culture.

Our demonstration of weak-to-moderate immunolabelling of IL- $1 \beta$ in selective alpha cells in $3 / 13$ non-diabetic autoantibody-negative donors and its virtual absence in the remaining ten donors, including those with new-onset diabetes, is novel but intriguing. The variable immunostaining also observed in non-diabetic autoantibody-positive donors and those with longer-duration diabetes may imply intrinsic heterogeneity of alpha cells within and between donors. It is unclear whether IL-1 $\beta$ from selective alpha cells functions as an autocrine or paracrine factor. Additional sources of IL-1 $\beta$ include macrophages and some $\mathrm{T}$ cells (shown here) and dendritic cells (shown in a Japanese study) and resident macrophages in human islets exposed to IFN- $\gamma+\operatorname{LPS}+\operatorname{TNF}[18,23]$. The origin of IL- $\beta$ in some $\mathrm{T}$ cells in a mouse model of autoimmune encephalomyelitis also supports our observations [24]. The extremely rare expression of IL-1 $\beta$ in beta cells from some of the non-diabetic and long-term diabetic donors observed in the present study is in contrast to a higher degree of expression reported in Japanese volunteers with new-onset type 1 diabetes and in humans with type 2 diabetes and may reflect differences in individuals' characteristics [14, 18]. The overall number of IL-1 $\beta$-positive cells reported in the Japanese study was also low. That study did not report the absolute number of IL-1 $\beta$-positive cells per insulin-positive and -negative islet so a direct comparison with our findings is not possible. In addition, differences in environmental exposure of donors in the two studies, time of diagnosis, ethnicity and genetic background makes a true comparison difficult.

A recent study has compared mRNA expression patterns for Illb, Tnf, Il6, Il17 and Ifng in four animal models of type 1 diabetes with cadaveric sections from humans with and without disease [25]. In this study, pancreas from humans with diabetes of unknown duration was found to express IL- $\beta$ and TNF- $\alpha$ in immune cells infiltrating islets by using an in 
situ hybridisation technique, which may not always correlate with immunohistochemistry.

During the preparation of this manuscript, an immunohistochemical analysis of pancreas sections from nPOD donors with type 1 and type 2 diabetes and non-diabetic donors with or without autoantibodies showed that all islet alpha cells were the major pancreatic source of IL-1 $\beta$ [26]. Our observations showing its variable expression in selective alpha cells suggest heterogeneity of this cell type. The published report, showing uniform staining of IL-1 $\beta$ in alpha cells, employed anti-IL-1 $\beta$ from Abcam, whereas we obtained it from Cell Signaling Technology. The latter antibody was validated for immunohistochemical monospecificity in our laboratory and by the suppliers by western blotting. Previous studies showing a low level of $I L 1 B$ mRNA in islets isolated from non-diabetic adult donors and from the same biopsy samples from the DiViD study, where its expression at the protein level was undetectable, are in agreement with our findings [9, 22]. Differences in properties of the antibody from the two sources and experimental protocols may explain some of the differences in results.

The role of systemic IL- $1 \beta$ as an effector of beta cell destruction remains unclear. A few reports show an increase in circulating IL-1 $\beta$ at the protein and mRNA level in the peridiagnostic period $[27,28]$. The net bioactivity of systemic IL$1 \beta$ may be confounded by oscillating levels and variable turnover of soluble receptors and receptor antagonists.

The significance of the unexpected lower IL-1 $\beta$-positive cell density observed in the exocrine region of the new-onset diabetes group compared with the autoantibody-positive non-diabetic and long-term diabetic groups is unclear. The expression pattern of cytokines in cadaveric pancreas may be profoundly influenced by the metabolic state of the donor preceding brain death and during cold ischaemia. These confounding variables are likely to be absent in biopsy samples from living new-onset volunteers who remain in an optimised metabolic state and are pancreatitis-free. It is possible that previous medical conditions seemingly unrelated to type 1 diabetes documented for some nPOD donors may have contributed to the increase in exocrine IL-1 $\beta$-positive cell density. An increase in the number of CD8 T cells in the exocrine region has been reported in $\mathrm{nPOD}$ donors with long-term type 1 diabetes [29]. We have also shown an increase in the number of leucocytic infiltrates in the same region of several individuals with longer-term type 1 diabetes [15]. This pathology may be consistent with the emerging view of the plasticity of exocrine macrophages, potentially driving them to an inflammatory phenotype, including cytokine production, or even towards an anti-inflammatory protective mode [30].

This study has carefully examined the cellular expression of a key cytokine implicated in beta cell destruction during type 1 diabetes. We analysed pancreas sections from one of the first biopsies carefully retrieved from young adults at diabetes onset and compared our findings with sections prepared from nondiabetic autoantibody-positive and -negative cadavers and those who had long-standing diabetes. An overall decrease in the mean number of IL-1 $\beta$-positive cells in the new-onset group, compared with the non-diabetic autoantibody-positive group, may suggest a pathological change. This requires further verification due to differences in tissue retrieval. Given the small sample size of this study, limited by the rarity of biopsies from living donors and the known marked intra- and interindividual heterogeneity of pathogenic processes within the islets during type 1 diabetes, generalisation of our findings to all individuals with new-onset diabetes is premature. Nonetheless, our study offers some key perspectives on the biology and dynamics of this important cytokine within the islet in new-onset diabetes and during disease of longer duration. We are cognisant that the DiViD donors were in better metabolic homeostasis during and immediately prior to biopsy whereas in cadaveric donors with long-term diabetes, variable degrees of metabolic de-compensation, hyperglycaemia-driven oxidative stress and cold ischaemia may have influenced the expression pattern of this labile cytokine. We also recognise the limitations of cross-sectional studies and that there may be regional differences in the frequency of IL-1 $\beta$-positive cells and their juxtaposition to the islets. Future non-invasive deeptissue molecular imaging techniques may provide valuable information regarding real-time IL- $1 \beta$ dynamics within the pancreas in early diabetes. Nonetheless, the present study provides new impetus to delineate the precise role of a key cytokine with reported opposing concentration-dependent biological effects on beta cells. Our immunohistochemical snapshot argues against locally produced IL- $1 \beta$ being a major mediator of beta cell destruction during early type 1 diabetes but implies its purported role in beta cell survival and function.

Acknowledgements We thank Cell Signaling Technology for the supply of THP-1 cells with and without exposure to LPS, for use as immunohistochemical controls. From the Faculty of Medical and Health Sciences, University of Auckland (Auckland, New Zealand), we thank P. Browett for ongoing encouragement, D. van der Werf for statistical advice and J. Chong and A. Lim for checking the manuscript and preparing and revising the final version of tables. We thank the DiViD study for supplying rare pancreatic tail sections following biopsy from living donors newlydiagnosed with type 1 diabetes and A. Pugliese, I Kusmartseva and their team from nPOD for ready advice and supply of valuable cadaveric pancreatic sections with anonymous donor clinical characteristics. A brief report based on some of our findings was presented at the 20157 th nPOD Scientific Meeting, St Pete Beach, FL, USA, and the Annual Scientific Meeting of the New Zealand Society for the Study of Diabetes, New Zealand, held in 2016 and 2017.

Data availability All original data are available from the corresponding author on request.

Funding We are grateful to the New Zealand Society for the Study of Diabetes for partial financial support for this study (SR). KD-J is the principal investigator of the DiViD study, which was funded by SouthEastern Norway Regional Health Authority (grant to KD-J), The Novo Nordisk Foundation (grant to KD-J) and through the PEVNET Study Group funded by the European Union's Seventh Framework Programme (FP7/2007-2013) under Agreement Number 26441 
PEVNET. The funding agencies were not involved in the design of the present study, the collection, analysis and interpretation of data, writing of the report or the decision to submit the report for publication.

Duality of interest The authors declare that there is no duality of interest associated with this manuscript.

Contribution statement SR conceived and designed the experimental studies, carried out a considerable portion of them, acquired and analysed the data, wrote and revised the manuscript critically for publication and led and directed the study. FW, LK and KD-J made significant contribution to the conception of the study and its design and data interpretation. They also assisted in critically reading and offering valuable advice in revising the manuscript for intellectual content. CM, RH, JC and HW assisted in designing the studies, performed part of the experimental studies, acquired multiple microscopic images from several samples, carried out further data analysis and read and revised the relevant parts of the manuscript for scientific content. In addition, following discussions with SR, CM prepared all figures and carried out careful statistical analysis. All authors have given their final approval of the version to be published. SR is the guarantor of the work.

\section{References}

1. Donath MY, Böni-Schnetzler M, Ellingsgaard H, Halban PA, Ehses JA (2010) Cytokine production by islets in health and diabetes: cellular origin, regulation and function. Trends Endocrinol Metab 21:261-267

2. Mandrup-Poulsen T, Bendtzen K, Nerup J, Egeberg J, Nielsen JH (1986) Mechanisms of pancreatic islet cell destruction dosedependent cytotoxic effect of soluble blood mononuclear cell mediators on isolated islets of Langerhans. Allergy 41:250-259

3. Mandrup-Poulsen T, Bendtzen K, Nerup J, Dinarello CA, Svenson M, Nielsen JH (1986) Affinity-purified human interleukin I is cytotoxic to isolated islets of Langerhans. Diabetologia 29:63-67

4. Cnop M, Welsh N, Jonas J-C, Jörns A, Lenzen S, Eizirik DL (2005) Mechanisms of pancreatic $\beta$-cell death in type 1 and type 2 diabetes. Diabetes 54(Suppl 2):S97-S107

5. Pirot P, Cardozo AK, Eizirik DL (2008) Mediators and mechanisms of pancreatic beta-cell death in type 1 diabetes. Arq Bras Endocrinol Metabol 52:156-165

6. Rabinovitch A, Sumoski W, Rajotte RV, Warnock GL (1990) Cytotoxic effects of cytokines on human pancreatic islet cells in monolayer culture. J Clin Endocrinol Metab 71:152-156

7. Berchtold L, Prause M, Størling J, Mandrup-Poulsen T (2016) Cytokines and pancreatic $\beta$-cell apoptosis. Adv Clin Chem 75: 99-158

8. Eizirik DL, Mandrup-Poulsen T (2001) A choice of death - the signal-transduction of immune-mediated beta cell apoptosis. Diabetologia 44:2115-2133

9. Welsh N, Cnop M, Kharroubi I et al (2005) Is there a role for locally produced interleukin- 1 in the deleterious effects of high glucose or the type 2 diabetes milieu to human pancreatic islets? Diabetes 54: 3238-3244

10. Mandrup-Poulsen T, Pickersgill L, Donath MY (2010) Blockade of interleukin 1 in type 1 diabetes mellitus. Nat Rev Endocrinol 6: 158-166

11. Spinas GA, Mandrup-Poulsen T, Mølvig J et al (1986) Low concentrations of interleukin-1 stimulate and high concentrations inhibit insulin release from isolated rat islets of Langerhans. Acta Endocrinol 113:551-558
12. Mandrup-Poulsen T (1996) The role of interleukin-1 in the pathogenesis of IDDM. Diabetologia 39:1005-1029

13. Arous C, Ferreira PG, Dermitzakis ET, Halban PA (2015) Short term exposure of beta cells to low concentrations of interleukin$1 \beta$ improves insulin secretion through focal adhesion and actin remodeling and regulation of gene expression. J Biol Chem 290: 6653-6669

14. Maedler K, Sergeev P, Ris F et al (2002) Glucose-induced $\beta$ cell production of IL- $1 \beta$ contributes to glucotoxicity in human pancreatic islets. J Clin Invest 110:851-860

15. Reddy S, Zeng N, Al-Diery H et al (2015) Analysis of peri-islet CD45-positive leucocytic infiltrates in long-standing type 1 diabetic patients. Diabetologia 58:1024-1035

16. Martin C, Krogvold L, Farik S et al (2017) An immunohistochemical study of nitrotyrosine expression in pancreatic islets of cases with increasing duration of type 1 diabetes and without diabetes. Histochem Cell Biol 147:605-623

17. Moran A, Bundy B, Becker DJ et al (2013) Interleukin-1 antagonism in type 1 diabetes of recent onset: two multicentre, randomised, double-blind, placebo-controlled trials. Lancet 381: 1905-1915

18. Uno S, Imagawa A, Okita K et al (2007) Macrophages and dendritic cells infiltrating islets with or without beta cells produce tumour necrosis factor- $\alpha$ in patients with recent-onset type 1 diabetes. Diabetologia 50:596-601

19. Krogvold L, Edwin B, Buanes T et al (2014) Pancreatic biopsy by minimal tail resection in live adult patients at the onset of type 1 diabetes: experiences from the DiViD study. Diabetologia 57:841-843

20. Pugliese A, Yang M, Kusmarteva I et al (2014) The Juvenile Diabetes Research Foundation Network for Pancreatic Organ Donors with Diabetes (nPOD) Program: goals, operational model and emerging findings. Pediatr Diabetes 15:1-9

21. Böni-Schnetzler M, Boller S, Debray S et al (2009) Free fatty acids induce a proinflammatory response in islets via the abundantly expressed interleukin-1 receptor I. Endocrinology 150:5218-5229

22. Krogvold L, Wiberg A, Edwin B et al (2016) Insulitis and characterisation of infiltrating $\mathrm{T}$ cells in surgical pancreatic tail resections from patients at onset of type 1 diabetes. Diabetologia 59:492-501

23. Arnush M, Heitmeier MR, Scarim AL et al (1998) IL-1 produced and released endogenously within human islets inhibits $\beta$ cell function. J Clin Invest 102:516-526

24. Martin BN, Wang C, Zhang C et al (2016) T cell-intrinsic ASC critically promotes TH17-mediated experimental autoimmune encephalomyelitis. Nat Immunol 17:583-592

25. Jörns A, Arndt T, Zu Vilsendorf AM et al (2014) Islet infiltration, cytokine expression and beta cell death in the NOD mouse, BB rat, Komeda rat, LEW.1AR1-iddm rat and humans with type 1 diabetes. Diabetologia 57:512-521

26. Anquetil F, Sabouri S, Thivolet C et al (2017) Alpha cells, the main source of IL-1 $\beta$ in human pancreas. J Autoimmun 81:68-73

27. Dogan Y, Akarsu S, Ustundag B, Yilmaz E, Gurgoze MK (2006) Serum IL-1 $\beta$, IL-2, and IL-6 in insulin-dependent diabetic children. Mediat Inflamm 2006:59206

28. Kaizer EC, Glaser CL, Chaussabel D, Banchereau J, Pascual V, White PC (2007) Gene expression in peripheral blood mononuclear cells from children with diabetes. J Clin Endocrinol Metab 92: 3705-3711

29. Rodriguez-Calvo T, Ekwall O, Amirian N, Zapardiel-Gonzalo J, von Herrath MG (2014) Increased immune cell infiltration of the exocrine pancreas: a possible contribution to the pathogenesis of type 1 diabetes. Diabetes 63:3880-3890

30. Calderon B, Carrero JA, Ferris ST (2015) The pancreas anatomy conditions the origin and properties of resident macrophages. J Exp Med 212:1497-1512 